\title{
The Effect of Capital Structure, Profitability Ratio and Liquidity Ratio on Share Prices (Studies on Manufacturing Companies in Southeast Asia)
}

\author{
Firman Ardiansyah, Agus Sukoco, Ani Wulandari \\ Faculty of Economics and Business \\ Narotama University Surabaya, Indonesia \\ firman.ardiansyah1997@gmail.com, agus.sukoco@narotama.ac.id \\ ani.wulandari@narotama.ac.id
}

\begin{abstract}
This study aims to analyze the effect of the influence of capital structure, profitability ratio and liquidity ratio on share prices (studies on manufacturing companies in southeast asia) 2017-2019. The sample used was 15 manufacturing companies with purposive sampling method. This research used quantitatif approach. The data collection techniques used are documentation in the form of secondary data and library research. The analysis of this research uses multiple linear regression. The results of this study are the capital structure, liquidity ratio and rentability ratio have a significant positive effect on stock prices simultaneously and partially.
\end{abstract}

Keywords :

Capital Structure, Liquidity Ratio, Profitability Ratio, Stock Price.

\section{Introduction}

According to the Central Statistics Agency (BPS), the production growth of large and medium-sized manufacturing industries in 2017 increased by $4.74 \%$ compared to the previous year. Head of BPS Suhariyanto said the increase was due to an increase in food industry production, which rose by $9.93 \%$. Meanwhile, the industry that experienced the largest decline in production was the Other processing industry, down $4.51 \%$. The production growth of large and medium manufacturing industries in the fourth quarter of 2017 increased by $5.15 \%$ (yoy) against the fourth quarter of 2016. The increase was mainly due to increased production of the food industry, up $15.28 \%$.

The production growth of large and medium manufacturing industries in the fourth quarter of 2017 (yon-y) at the provincial level that experienced the highest growth was DKI Jakarta, up 16\%. Meanwhile, the province that experienced a decline in growth was Jambi Province, down 6.54\%

The production growth of large and medium manufacturing industries in the fourth quarter of 2017 (q-toq) at the provincial level that experienced the highest growth was Southeast Sulawesi Province, up 10.22\%. Meanwhile, the province that experienced a decline in growth was South Sumatra Province, down 15.93\%.

The manufacturing sector is considered the key to economic growth. Therefore, the manufacturing sector must be developed, so that economic growth can run. This is because the manufacturing-based trade and industry sectors have become the foundation of economic growth in several countries in the Southeast Asian region, such as the Philippines and Vietnam. Minister of Industry Airlangga Hartarto also explained that the export contribution of the manufacturing industry to the economy was still high.

Based on World Bank national accounts data, and OECD National Accounts data files that the value added Gross domestic product from 2017 to 2019 has increased rapidly. We can see from the graph above from 2017 to 2019 that GDP has increased rapidly. 
Figure 1.GDP data of manufacturing companies for the 2017-2019 period

\section{Literature Review}

2.1 Capital Structure

Brigham (2006), conducted a research on the company's capital structure, namely that the variables that affect the capital structure are sales stability, asset structure, operating leverage, growth rate, profitability, taxes, control, management attitudes, attitudes of lenders and rating agents, market conditions. , internal company conditions, and financial flexibility".

\subsection{Profitability Ratio}

According to Munawir (2010) : "Profitability is the company's ability to generate profits for a certain period." So from the various opinions above, it can be concluded that profitability is the ratio between profit and capital that produces this profit.

\subsection{Liquidity Ratio}

Kasmir, (2013) states that the liquidity ratio is to show or measure the company's ability to meet its maturing obligations, both obligations to parties outside the company and within the company. In this study, the ratio used to measure the level of company liquidity is the Current Ratio. Current Ratio is a comparison between current assets and current liabilities and is the most commonly used measure to determine a company's ability to meet its short-term obligations. Current Ratio shows the extent to which current assets cover current liabilities. The greater the ratio of current assets and current liabilities, the higher the company's ability to cover its shortterm liabilities

\subsection{Stock Price}

Shares can be defined as a sign of participation or ownership of a person or entity in a company or limited liability company. The form of shares is a sheet of paper which states that the owner of the paper is the owner of the company that issued the securities. The portion of ownership is determined by how much investment is invested in the company (Darmadji, 2001). 


\section{Research Concept Framework}

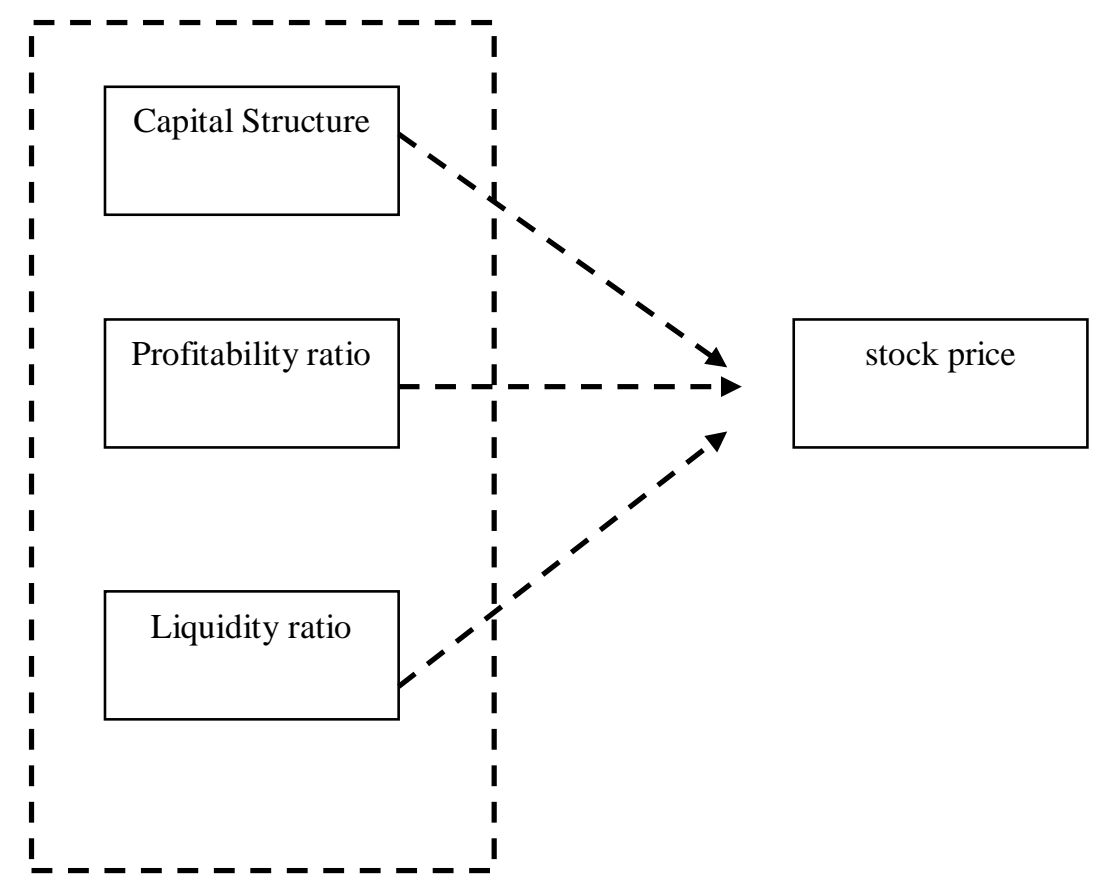

\section{Methodology}

This research used descriptive quantitative external secondary data as research material. Secondary data used is in the form of financial statements of manufacturing companies in Southeast Asia 2017-2019. In this study the data includes capital structure, profitability ratios, and liquidity ratios as independent variables, stock prices as intervening variables and. The sampling method using purposive sampling method, with a sample size of 15 companies. Samples were selected based on selection criteria.

Data collection techniques are the most strategic steps in research, because the main purpose of the study is to collect data (Sugiyono, 2009) The data collection technique in this study uses documentation techniques by finding and collecting data related to research problems to get the right information. The documentation method is used to collect financial reports on manufacturing companies for the 2017-2019 period. The second data collection method used in this study is library research. Library research is a way of collecting data through library media in the form of Company Annual Reports, books, journals and other literature related to the issues studied.

This study uses multiple linear regression models in analyzing data. This model is used to determine how much influence the independent variable has on the dependent variable, namely Debt to Total Assets Ratio (DAR), Return On Assets (ROA) and Curent Ratio (CR) on stock prices of manufacturing companies in Southeast Asia. Based on the framework that has been written, this research model can be mathematically written as follows:

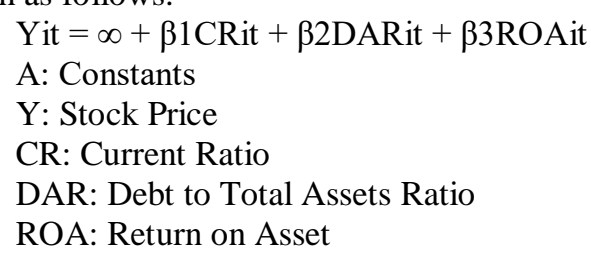

\section{Research and Discussion}

\subsection{Descriptive Research Results}

Description of research data is the process of collecting, presenting and summarizing which functions to provide an adequate overview of the data under study. Data processing was carried out with the help of the SPSS 21 statistical program and obtained the following descriptions of research data: 
Table 1. Results Description of Research Data

Descriptive Statistics

\begin{tabular}{cccccc}
\hline & $\mathrm{N}$ & Minimum & Maximum & Mean & Std. Deviation \\
\hline DAR & 45 & .00 & 8.27 & .6336 & 1.23205 \\
ROA & 45 & .00 & 35899.41 & 799.0998 & 5351.37021 \\
CR & 45 & .51 & 189.56 & 10.6436 & 38.86866 \\
Harga Saham & 45 & .20 & 83800.00 & 10316.4752 & 24824.05168 \\
Valid N (listwise) & 45 & & & & \\
\hline
\end{tabular}

Data source: SPSS 21

From the table above, it will be explained as follows:

\subsubsection{Debt to Assets Ratio (DAR)}

Based on the test results in the table above, it can be seen that the minimum value of Debt to Assets Ratio is 0.00 and the maximum value is 8.27. This shows that the value of the Debt to Assets Ratio in the sample of this study ranged from -0.00 to 8.27 with an average (mean) of 0.63 at the standard deviation of 1.23 . The mean average value is smaller than the standard deviation, which is $0.63<1.23$, which means that the distribution of the Debt to assets ratio value is not good, that is, there is too large a gap between the lowest value and the highest value of the Debt to assets ratio variable during the period. research.

\subsubsection{Return On Assets (ROA)}

The test results in the table above, it can be seen that the minimum value of Return On Assets is 0.00 and the maximum value is 35899.41. This shows that the value of the Return On Assets in the sample of this study ranged from 0.00 to 35899.41 with an average (mean) of 799.0998 at a standard deviation of 5351.37021. The mean average value is smaller than the standard deviation, which is 799.0998> 5351.37021, which means that the distribution of the Return On Assets value is not good, that is, there is too large a gap between the lowest and highest values of the Return On Assets variable during the study period.

\subsubsection{Current Ratio (CR)}

Based on the test results in the table above, it can be seen that the minimum value of the Current Ratio is 0.51 and the maximum value is 189.56 This shows that the value of the Current Ratio in the sample of this study ranges from 0.51 to 189.56 with an average (mean) 10.64 at standard deviation of 38.87 . The mean average value is smaller than the standard deviation, which is $10.64<38.87$, which means that the distribution of the current ratio value is not good. The data is homogeneous, there is no too big gap between the lowest and highest values of the Current Ratio variable during the study period.

\subsubsection{Share Price}

Based on the test results in the table above, it can be seen that the minimum value of the Share Price is 0.20 and the maximum value is 83800.00 . This shows that the value of the stock price in the sample of this study ranged from 0.20 to 83800.00 with an average (mean) of 10316.4752 at the standard deviation of 24824.05168. The mean average value is smaller than the standard deviation, which is 10316.4752 $<24824.05168$, which means that the distribution of the value of the stock price is not good, that is, there is too big a gap between the lowest value and the highest value of the stock price variable during the study period.

\subsection{Classic Assumption Test}

The classical assumption test is a requirement that must be met in multiple linear regression analysis based on Ordinary Least Square (OLS), which is one of the methods in multiple linear regression analysis to determine the effect of independent variables on dependent variables. The classic assumption test in this study is used to determine the relationship between the research variables in the regression model.

\subsection{Data Normality Test}

The normality test aims to test whether in the regression model, confounding or residual variables have a normal distribution (Ghozali, 2013). A good regression model is to have a residual value that is normally distributed. So the normality test is not carried out on each variable but on its residual value. Normality test can be done by histogram, normal P Plot test, Chi Square test, Skewness and Kurtosis or Kolmogrof Smirnov test. In this study, to test the normality of the data used the Kolmogrof Smirnov test, the basis for making decisions is as follows:

1) The number of significance ( $\mathrm{sig})>0.05$, the data is normally distributed.

2) The number of significance ( $\mathrm{sig}$ ) $<0.05$, the data is not normally distributed. 


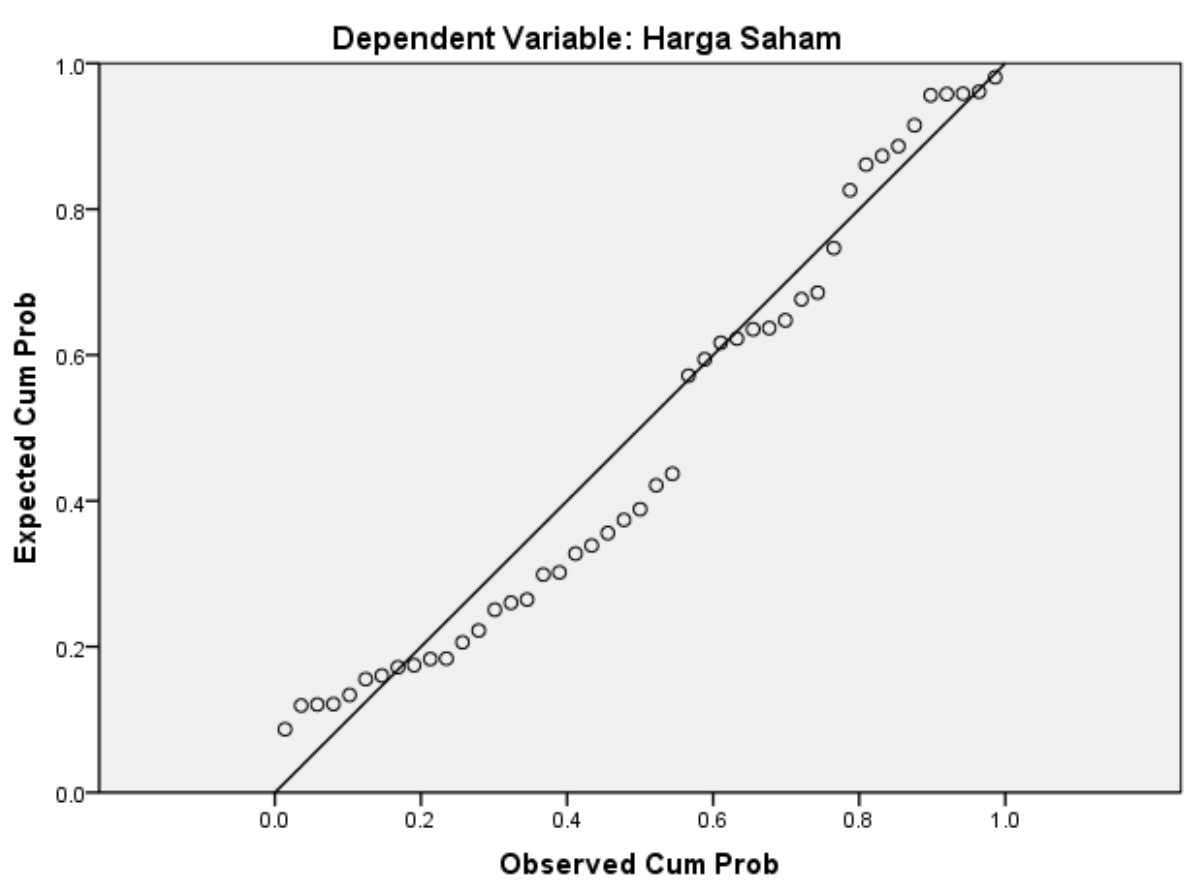

Figure 2. Normal P-P Plot of Regission Standardized Residual Dependent Variabel : Haga Saham

Based on the output "Chart" above, we can see that the plot points in the "Normal P-P Plot of Standardized Residual Regression" figure always follow and approach the diagonal line. Therefore, as the basis or guideline for decision making in the probability plot technique normality test, it can be concluded that the residual value is normally distributed. Thus, the normality assumption for residual values in the simple linear regression analysis in this study can be fulfilled.

\subsection{Multicollinearity Test}

The multicollinearity test is to see whether or not there is a high correlation between the independent variables in a multiple linear regression model. If there is a high correlation between the independent variables, then the relationship between the independent variables and the dependent variable will be disturbed. This multicollinearity test can be seen from the tolerance value and variance inflation factor (VIF). This tolerance measures the selected independent variable which cannot be explained by other independent variables. So if a low tolerance value is the same as a high VIF value (because VIF $=1 /$ tolerance), then this indicates high collinearity. The cut off value that is commonly used is a tolerance value of 0.10 or a VIF value which is below the value of 10 . Thus, multicollinearity occurs when the tolerance value is $<0.10$ or the VIF value $>10$ (Ghozali, 2013)

Coefficients $^{\mathrm{a}}$

Table 2. Multicollinearity Test

Correlations Collinearity Statistics

\begin{tabular}{ccccc} 
Zero-order & Partial & Part & Tolerance & VIF \\
& & & & \\
\hline,- 024 &,- 074 &,- 066 &, 981 & 1,020 \\
, 455 &, 456 &, 453 &, 993 & 1,007 \\
,- 101 &,- 094 &,- 083 &, 983 & 1,017 \\
\hline \multicolumn{7}{c}{ Dependent Variable: HS }
\end{tabular}

Based on the table above, it shows the VIF calculation, it can be concluded that the model does not occur multicollinearity between the independent variables, because the VIF value of each is smaller than 10. 


\subsection{Heteroscedasticity Test}

Heteroscedasticity test is to see whether the variance inequality from one residual to another observation. Regression models that meet the requirements are where there is a similarity in variance from one observation to another, which is fixed or called homoscedasticity. Heteroscedasticity detection can be done by using the Glesjer test method. The basis for making decisions on the Heteroscedasticity Test are:

1) If the significance value is greater than 0.05 , heteroscedasticity does not occur.

2) If the significance value is smaller than 0.05 , heteroscedasticity occurs

Table 3. Heteroscedasticity coeffisients

\begin{tabular}{ccccccc}
\hline & Model & \multicolumn{5}{c}{ Standardized } \\
& & \multicolumn{2}{c}{ Unstandardized Coefficients } & Coefficients & & \\
\hline 1 & B & Std. Error & Beta & T & Sig. \\
\hline & (Constant) & 9897.567 & 4203.065 & & 2.355 & .023 \\
& DAR & -613.760 & 2920.040 & -.030 & -.210 & .835 \\
& ROA & 1.745 & .668 & .376 & 2.614 & .012 \\
& CR & -55.150 & 92.616 & -.086 & -.595 & .555 \\
\hline
\end{tabular}

a. Dependent Variable: Stock Price

Based on the results of the Glesjer test above, the significance value of the Debt Assets Ratio variable is 0.835 and is greater than 0.05 , so the data for the Debt Assets Ratio variable is said to have no heterosedasticity. The significance value of the Return On Assets variable is 0.012 and is greater than 0.05 , so the data on the Return On Assets variable is said to be heterosedasticity. The significance value of the Current Ratio variable. amounting to 0.555 and greater than 0.05 , then the Current Ratio variable data is said to have no heterosedasticity.

Table 4. Model Summary ${ }^{\mathrm{b}}$

\begin{tabular}{|c|c|c|c|c|c|}
\hline Model & $\mathrm{R}$ & R Square & $\begin{array}{l}\text { Adjusted R } \\
\text { Square }\end{array}$ & $\begin{array}{l}\text { Std. Error of the } \\
\text { Estimate }\end{array}$ & Durbin-Watson \\
\hline 1 & $.390^{\mathrm{a}}$ & .152 & .090 & 23680.74785 & 2.236 \\
\hline j & & & & & \\
\hline 1 & & & & & \\
\hline 1 & & & & & \\
\hline 1 & & & & & \\
\hline$:$ & & & & & \\
\hline i & & & & & \\
\hline 1 & & & & & \\
\hline 1 & & & & & \\
\hline 1 & & & & & \\
\hline
\end{tabular}

a. Predictors: (Constant), CR, ROA, DAR

b. Dependent Variable: Harga Saham

From the test table of the coefficient of determination, it can be seen that the Adjusted R Square value is 0.090 or $9 \%$ so it can be concluded that the independent variables (Debt to Assets Ratio, Return on Assets and Current Ratio) in this regression model can explain the dependent variable (Stock Price) of $9 \%$, while the remaining $91 \%$ is influenced by other variables not taken into account in this study.

\subsection{Multiple Linear Regression Test}

Regression analysis is a method or technique to find a relationship between one variable and another which is expressed in a mathematical equation in a functional relationship. In another sense, regression analysis seeks to find the relationship of two or more variables, where one variable depends on the other variable. In general, it can also be stated that if you want to know the effect of one variable $\mathrm{X}$ on one variable $\mathrm{Y}$, simple linear regression analysis is used, and if you want to know the effect of two or more variables $\mathrm{X}$ on variable $\mathrm{Y}$, multiple linear regression analysis is used. Multiple linear regression equation in the formula:

Where :

$$
\mathrm{Y}=\alpha+\beta_{1}, X_{1}+\beta_{2}, X_{2}+\beta_{3}, X_{3}+\mathrm{e}
$$

$$
\begin{array}{ll}
\alpha & =\text { Constant } \\
\beta_{1}-\beta_{3} & =\text { Regression coefficient } \\
\mathrm{Y} & =\text { Price Earning Ratio (PER) }
\end{array}
$$




\begin{tabular}{|c|c|}
\hline$X_{1}$ & $=$ Current Ratio $(\mathrm{CR})$ \\
\hline$X_{2}$ & $=$ Debt to Equity Ratio (DER) \\
\hline$X_{3}$ & $=$ Net Profit Margin $(\mathrm{NPM})$ \\
\hline$e$ & $=$ Residual error (error) \\
\hline
\end{tabular}

Coefficients $^{\mathrm{a}}$

Table 5. Multiple Linear Regression Test Results

\begin{tabular}{|c|c|c|c|c|c|c|c|c|}
\hline \multicolumn{2}{|c|}{ Model } & \multicolumn{2}{|c|}{ Unstandardized Coefficients } & \multirow{2}{*}{$\begin{array}{c}\text { Standardized } \\
\text { Coefficients } \\
\text { Beta }\end{array}$} & \multirow[t]{2}{*}{$\mathrm{t}$} & \multirow[t]{2}{*}{ Sig. } & \multicolumn{2}{|c|}{ Collinearity Statistics } \\
\hline & & B & Std. Error & & & & Tolerance & VIF \\
\hline \multirow{4}{*}{1} & (Constant) & 9556,905 & 4055,338 & & 2,357 & ,023 & & \\
\hline & DAR & $-1342,253$ & 2808,445 &,- 067 &,- 478 & 635 & 981 & 1,020 \\
\hline & ROA & 1207,490 & 368,039 & ,455 & 3,281 & ,002 & 993 & 1,007 \\
\hline & $\mathrm{CR}$ & $-53,557$ & 88,918 &,- 084 &,- 602 & ,550 & 983 & 1,017 \\
\hline
\end{tabular}

a. Dependent Variable: HS

From the table of the results of the Multiple Linear Regression Test above, it can be concluded that the regression equation generated in this study is:

Share Price $=9556.905-1342.905$ DAR $-1,286$ ROA -0.686 CR

The multiple linear regression equation above, can be explained as follows:

The constant is 9556.905, meaning that if DAR (X1), Debt to Assets Ratio (X2), and CR (X3) are 0 (zero), then the share price value (Y) is 9556.905

The regression coefficient for the DAR variable (X1) is $-342,253$, meaning that if the other independent variables ROA and Net CR are fixed in value, and the DAR variable has increased by $1 \%$, the share price value (Y) will decrease by $-1342,253$. The coefficient is negative, meaning that there is a negative relationship between DAR and stock prices, meaning that an increase in the DAR variable will decrease the share price variable.

The regression coefficient for the ROA variable (X2) is $-1207,490$, meaning that if the other independent variables DAR and CR are fixed in value, and the ROA variable increases by $1 \%$, the share price value (Y) will decrease by 1207,490 . The coefficient is negative, meaning that there is a negative relationship between ROA and stock prices, meaning that an increase in the ROA variable will reduce the variable stock price.

The regression coefficient for the CR variable (X3) is -53.557 , meaning that if the other independent variables DAR and ROA are fixed in value, and the CR variable has increased by $1 \%$, then the stock price value (Y) will decrease by -53.557 . The coefficient is negative, meaning that there is a negative relationship between $\mathrm{CR}$ and stock prices, meaning that a decrease in the Net $\mathrm{CR}$ variable will reduce the variable stock price.

\subsection{Statistical Test $\mathbf{F}$}

\begin{tabular}{ccccccc}
\multicolumn{7}{c}{ Table 6 Statistical Test F } \\
ANOVA
\end{tabular}

a. Predictors: (Constant), CR, ROA, DAR

b. Dependent Variable: Harga Saham

c. Dependent Variable: Stock Price

Based on the data in the table above, it is known that the Fcount value obtained is 2.450 with a significance value of 0.077 , the F count value is $2.450>\mathrm{F}$ table is 3.27 which means that DAR, ROA and CR have a significant effect on stock prices. The Sig value is $0.077>0.05$. So it can be concluded that H_0 and H_a are accepted, or it can be said that the variables DAR, ROA and CR simultaneously (together) have a significant effect on stock prices. 


\begin{tabular}{|c|c|c|c|c|c|c|}
\hline & \multirow[t]{2}{*}{ Model } & \multicolumn{2}{|c|}{ Unstandardized Coefficients } & \multirow{2}{*}{$\begin{array}{c}\text { Standardized } \\
\text { Coefficients } \\
\text { Beta } \\
\end{array}$} & \multirow[t]{2}{*}{$\mathrm{t}$} & \multirow[t]{2}{*}{ Sig. } \\
\hline & & B & Std. Error & & & \\
\hline \multirow{4}{*}{1} & (Constant) & 9556,905 & 4055,338 & & 2,357 & ,023 \\
\hline & DAR & $-1342,253$ & 2808,445 &,- 067 &,- 478 & 635 \\
\hline & ROA & 1207,490 & 368,039 & ,455 & 3,281 & ,002 \\
\hline & $\mathrm{CR}$ & $-53,557$ & 88,918 &,- 084 &,- 602 & ,550 \\
\hline
\end{tabular}

a. Dependent Variable: HS

b. Dependent Variable: PER

Source: SPSS Processed Data

The results of the data using SPSS obtained a DAR t-value of -0.478 with a significance value of 0.635.The t-count value of $-0.478>\mathrm{t}$-table 1.68957 means that Current DAR has a significant effect on stock prices, a significance value of 0.635 is greater than 0.05 . or $0.90>0.05$ means that DAR has no significant effect on stock prices. So that H_0 is accepted and H_1 is rejected.

The results of the data using SPSS obtained an ROA t-value of 3.281 with a significance value of 0.002.The t-count value of 3.281> t-table 1.68957 means that ROA has a significant effect on stock prices, a significance value of 0.002 is less than 0.05 or $0.90>0.05$ means that ROA has a significant effect on stock prices. So that H_0 and H_1 are accepted.

The results of the data using SPSS obtained a CR t-value of -0.602 with a significance value of 0.550.The t-count value of -0.602> t-table 1.68957 means that CR has a significant effect on stock prices, the significance value of 0.550 is less than 0.05 or $0.008>0.05$ means that $C R$ has a significant effect on stock prices. So that H_0 and H_1 are accepted.

\section{Conclusions and Recommendations 6.1 Conclusion}

This study aims to determine the effect of fundamental factors and economic conditions on stock prices of manufacturing companies in Southeast Asia for the 2017-2019 period. Based on the results of the analysis, the conclusions that can be drawn from this study are as follows:

1. The results of the data using SPSS obtained a DAR t-value of -0.478 with a significance value of 0.635.The t-count value of $-0.478>$ t-table 1.68957 means that DAR has a significant effect on stock prices, a significance value of 0.635 is greater than 0.05 . or $0.90>0.05$ means that DAR has no significant effect on stock prices. So that H_0 is accepted and H_1 is rejected.

2. The results of the data using SPSS obtained an ROA t-value of 3.281 with a significance value of 0.002.The t-count value of 3.281> t-table 1.68957 means that ROA has a significant effect on stock prices, a significance value of 0.002 is less than 0.05 or $0.90>0.05$ means that ROA has a significant effect on stock prices. So that H_0 and H_1 are accepted.

3. The results of the data using SPSS obtained a CR t-value of -0.602 with a significance value of 0.550 . The $t-$ count value of -0.602> t-table 1.68957 means that $\mathrm{CR}$ has a significant effect on stock prices, the significance value of 0.550 is less than 0.05 or $0.008>0.05$ means that CR has a significant effect on stock prices. So that H_0 and H_1 are accepted.

4. Based on the data in the table above, it is known that the value of F count obtained is 2.450 with a significance value of 0.077 , the value of Fcount is $2.450>\mathrm{F}$ table is 3.27 which means that DAR, ROA and CR have a significant effect on stock prices. The Sig value is 0.077> 0.05. So it can be concluded that H_0 and H_a are accepted, or it can be said that the DAR, ROA and CR variables simultaneously (together) have a significant effect on stock prices.

\subsection{Suggestion}

Based on the research results and conclusions above, the suggestions that can be given regarding the development of manufacturing companies in Southeast Asia are as follows: 


\subsubsection{For the Company}

Companies should improve company performance each year so that they are able to compete in gaining the trust of investors, making it easier to obtain capital from outside the company. The better the company's performance, one of which can be reflected in the higher ROA value, so that the company needs to increase the ROA value to gain the trust of investors.

\subsubsection{For Prospective Investors}

Prospective investors, when they want to invest, should consider DAR and ROA and CR, because they are proven to affect the stock price of the invoice company for the 2017-2019 period.

\section{Refrences}

Brigham, E. F. dan H. (2006). Fundamental of FinancialManagement: Dasar-Dasar Manajemen Keuangan edisi 10. Selemba Empat.

Darmadji, M. D. M. F. (2001). Pasar Modal Di Indonesia. Selemba Empat.

Ghozali, I. (2013). Aplikasi Analisis Multivariate dengan Program IBM SPSS 21 Update PLS Regresi. Badan Penerbit Universitas Diponegoro.

Kasmir. (2013). Analisis Laporan Keuangan. Rajawali Pers.

Munawir, S. (2010). Analisis laporan Keuangan Edisi keempat. Cetakan Kelima. liberty.

Sugiyono. (2009). Metode Penelitian Kuantitatif, Kualitatif dan R\&D. Alfabeta. 